\title{
Do Positive or Negative Experiences that Soccer Referees are Exposed in Their Social Lives Affect Their Competition Managements?
}

\author{
Mehtap Yıldız ${ }^{1}$ Özer Yıldız \\ ${ }^{1}$ Faculty of Education, Necmettin Erbakan University, Konya, 42090, Turkey \\ Correspondence: Özer Yıldız, Faculty of Education, Necmettin Erbakan University, Konya, 42090, Turkey.
}

Received: January 16, 2019

Accepted: February 26, 2019

Online Published: March 6, 2019

doi:10.11114/jets.v7i4.3976

URL: https://doi.org/10.11114/jets.v7i4.3976

\begin{abstract}
The purpose of this study is to examine the effects of positive or negative experiences of soccer referees on competition management in their social lives. In research interview method, one of the qualitative research patterns, was used. The study group was consisted of 13 male soccer referees from Turkey in 2018-2019 soccer season. As data collection tools personal information form and interview form were used. The data were analyzed through content analysis method. As a result of the research, some soccer referees stated that they try to manage fair matches even if they face negative situations in their social lives, and they shouldn't reflect these feelings in competitions if they live in their social lives. However, some referees stated that they experienced stress and concentration in competitions when they experienced negative emotions and not to experience these kind of things matches should be given back then even if they carry on to manage the match they specified that there might be false decisions made.
\end{abstract}

Keywords: soccer, referee, social live, competition management

\section{Introduction}

Individuals experience various emotions every moment of their lives and these feelings affect them positively or negatively. The effect of emotions on individuals' decisions is also known reality. Hence, it can be said that emotions are an integral part of decisions and affect the thoughts and behaviors of individuals.

In spite of the simple or complex problems faced by individuals in every period of their lives, the decision-making process is carried out continuously in both private and business life (Rue and Byers, 2003). How individuals think, analyze and assess the current situation in sports environments is an important research topic (Bar-Eli and Raab, 2006).

The transformation of soccer into an industrial character in recent years has influenced all the elements related to soccer game and it has become a necessity to manage all the elements of soccer with more professional structures (Katırc1, 2009). One of the important professional jobs in modern soccer is refereeing. It is important that the referees have equal distance to both sides and that the decisions to be made during competitions are fair (Gümüş, 2009).

The fact that soccer referees are the only managers in the field causes the discussion of the competition management. However, it is thought that the social experiences of the referees may be effective in their administration. For this reason, it is important to determine who the referees are, their level of education, their social lives and their problems (Tekin et al., 2005).

While Mckeon (2003) features of modern soccer referees; human management, self-confidence, determination, his work to enjoy, insisting that the ranking, Grunska (2011) tells that features of a good referee; honesty, courage, self-confidence, determination, consistency, coolness, modesty, human nature to understand and control events as listed. However, soccer referees should know the rules of the game very well and govern the game in accordance with the rules (Collina, 2004).

There are many stress factors under the influence of referees. Therefore, the referees' ability to manage competitions in a good way is very important. The level of anxiety may negatively affect the course of the match when the referees perform successfully (Dohmen, 2008). The anxiety and stress situations of the referees' social lives make it difficult for them to intensify their attention and choose the warnings they need in a competition (Rushall and Lippman, 1997). The social environment and daily personal relationships, in which referees live, affect their decisions and evaluations in competition management (Scoppa, 2009). For this reason, it is important that the soccer referees are not only physically 
prepared but also psychologically (Çoban, 2004).

It was determined that soccer referees were conducting researches about the situation of spectators, athletes and managers during the competition, but there were no studies on the effect of social lives on competition management. The purpose of this study is to examine the effects of positive or negative experiences in referees' competition managements which they expose in their social lives.

\section{Method}

The research was carried out as a phenomenology model, one of the qualitative research methods. The phenomenology model provides an in-depth understanding of the meaning and nature of everyday experiences of individuals (Patton, 2014). It was tried to determine how the referees experienced soccer competition management and the common aspects of the referees who experienced the same phenomenon (Creswell, 2007). So interview method was used to analyze the research topic with its all possible details (Yıldırım and Şimşek, 2006) and to define the ideas of individuals about the problems (Punch, 2005).

\subsection{Study Group}

The study group is consisted of 13 male soccer referees from Turkey in 2018-2019 soccer season. Soccer referees who participated in the study were coded as 'R1, R2, R3, etc.' in the data set (Table 1).

\subsection{Data Collection Tools}

There were 4 questions in the personal information form and there was 1 open ended question in the interview form. Personal information form and interview form were prepared by the researchers.

\subsection{Data Analysis}

The data were evaluated through the content analysis method. Content analysis is a scientific approach that investigates the social truth by classifying the messages contained in written materials objectively and systematically in terms of grammar and meaning, and converting them into numbers and making inferences. Reliability analysis of the data was carried out through Miles and Huberman (1994) formula (Tavşanc1l and Aslan, 2001):

$$
\text { Percentage of Agreement }=\frac{\text { Number of Agreement Themes }}{\text { Number of Agreement }+ \text { Disagreement Themes }} \times 100
$$

There must be a reliability percentage of at least $70 \%$ of the compliance achieved. According to the formula, 5 out of 6 codes were approved, and an agreement was settled at 5/6x100 and as a result of the evaluations of the three experts in this direction, the percentage of compliance in the themes was found to be $83.3 \%$.

\section{Results}

Table 1. Results of the soccer referees regarding age, the duration of refereeing experience, educational status, marital status, and interview date

\begin{tabular}{cccccc}
\hline Codes & Age & $\begin{array}{c}\text { Duration of Refereeing } \\
\text { Experience }\end{array}$ & $\begin{array}{c}\text { Educational } \\
\text { Status }\end{array}$ & $\begin{array}{c}\text { Marital } \\
\text { Status }\end{array}$ & $\begin{array}{c}\text { Interview } \\
\text { Date }\end{array}$ \\
\hline R1 & 30 & 10 & Bachelor & Married & 10.05 .2018 \\
\hline R2 & 37 & 8 & High School & Married & 10.05 .2018 \\
\hline R3 & 33 & 14 & Bachelor & Married & 10.05 .2018 \\
\hline R4 & 28 & 9 & Bachelor & Single & 10.05 .2018 \\
\hline R5 & 28 & 6 & Bachelor & Single & 10.06 .2018 \\
\hline R6 & 29 & 6 & Bachelor & Single & 10.06 .2018 \\
\hline R7 & 29 & 7 & Bachelor & Married & 10.06 .2018 \\
\hline R8 & 25 & 6 & Master's degree & Single & 10.07 .2018 \\
\hline R9 & 32 & 12 & Doctoral degree & Sarried & 10.07 .2018 \\
\hline R10 & 34 & 13 & Bachelor & Married & 10.07 .2018 \\
\hline R11 & 26 & 8 & Bachelor & Married & 10.08 .2018 \\
\hline R12 & 38 & 15 & Bachelor & Bachelor & 10.08 .2018 \\
\hline R13 & 36 & 18 & arried
\end{tabular}

When the Table 1 is examined, it is found that their ages are between 25 and 38, the duration of refereeing experience are between 6 and 18,1 soccer referee has doctoral degree, 1 soccer referee has master's degree, 10 soccer referees have bachelor degree, 1 soccer referee has high school degree regarding their educational status, 8 soccer referees are married and 5 soccer referees are single. 
Table 2. Results related to thoughts of soccer referees about positive or negative experiences that they are exposed in their social lives

\begin{tabular}{lcc}
\hline \multicolumn{1}{c}{ Themes } & Frequency (f) & Percentage (\%) \\
\hline Trying to Manage a Fair Match & 4 & 30.8 \\
\hline Social Life Should not be Reflected to the Refereeing & 4 & 30.8 \\
\hline Stress and Lack of Concentration & 2 & 15.4 \\
\hline Returning the Competition & 2 & 15.4 \\
\hline Cause to Wrong Decision & 1 & 7.6 \\
\hline Total & 13 & 100 \\
\hline
\end{tabular}

When Table 2 is examined, one of the situations most frequently expressed by soccer referees' positive or negative experiences in their social lives in their opinions about competition management is the "Trying to Manage a Fair Match" theme. In the interviews, the participants expressed this situation with these sentences:

"... A person may go through everything. We need to manage the match equally for both teams and we should be fair ..."(R1)

"... we believe that we overcome the negative experiences during the match because we are professional. We look out for justice without letting it affect the game. "(R4)

Another one of the most frequently stated situations in the opinions of the soccer referees about the management of competitions was the theme of "Social Life should not be Reflected to the Refereeing". In the interviews, the participants expressed this situation with these sentences:

"Social life is a separate arbitration life for me. I try not to reflect anything in social life to my refereeing life... When one enters into the referee room everything must be remained outside. For this reason, I usually try not to reflect on the events I normally live in normal life. I motivate myself in that way." (R5).

"... we as referees are the people who totally focus ourselves on the match. Social life problems should not be reflected in the matches ..." (R6)

In the research "Stress and Lack of Concentration" was the second most common case of soccer referees' positive or negative experiences they are exposed in their social life. In the interviews, the participants expressed this situation:

"Bad things in our social life are definitely affecting our refereeing... We have difficulty concentrating on the competition when negative things come to mind."(R2)

$" . .$. Social life sometimes puts me into the stress. This is sometimes a problem in gathering attention in games..."(R8)

Another one of the second cases that the soccer referees expressed in the social lives of the positive or negative experiences that they were exposed to in their opinion about competition management was the theme of "Returning the Competition". In the interviews, the participants expressed this situation:

"There may be negative things in my social life, such as death. If there is such a thing, we need to inform the jury that we cannot manage the match with that psychological state by giving information to the jury."(R7)

Soccer referees who participated in the survey in their social lives of the positive or negative experiences of their opinion about the management of events in the least frequency of the situation "Cause to Wrong Decision" has been the theme. In the interviews, one participant expressed this situation:

"... I had to go to the match the day I found out my uncle had passed away. I wanted not to think too much, but of course I had one or two mistakes. All kinds of things can happen to us, there is not such thing that the referees don't make mistakes..." (R12)

\section{Discussion and Conclusion}

As a result of the research, one of the most stated situations by soccer referees was that they specified that they had positive or negative emotions with their family, business and friends in their social lives, but that social life was trying to manage the matches fairly without letting them influence competition management. Soccer referees also live in a social environment and sometimes feel sad when they rejoice. It is particularly difficult to manage competitions when they are sad and unhappy. Yet, the participants, however, stated that they tried to show the necessary care to manage a fair match. Nevill et al. (2002) determined that the experienced soccer referees act with a sense of duty while making decisions in stressful environments.

In fact, it can be said that the negative emotions experienced by the referees can inevitably affect their decisions. Because the debates in people's lives, the bad news they receive will deteriorate their morale and cause their thoughts to be affected for a certain period of time. Scoppa (2009) indicated that soccer referees can be affected by all kinds of 
external factors and can make subjective evaluations. Marcora (2009) stated that mental fatigue affects physical activity performance. Eygü (2009) reached out the result that the referees' family problems caused a loss of motivation during the matches.

Soccer referees state that one of the most expressive situations in their lives naturally experienced many emotions, but they have earned a professional point of view in refereeing these feelings did not allow reflection to referees. Grunska (2011) stated that the referees should be persons who are observing the rules. Guillen and Feltz (2011) determined that a good soccer referee is the one who applies the rules of the game and who are consistent, determined, equal, honest and trusting. Baştuğ et al. (2016) found that the self-confidence of soccer referees increased and their decision-making skills increased. Gülle et al. (2017) concluded that among the referees of soccer, those who were more experienced and those who were not exposed to violence had higher self-esteem in their decision-making levels.

Feelings of soccer referees may increase or decrease their motivation. Although the referees state that they will not reflect their social lives to arbitration, it can be said that negative emotions may cause their motivation to decrease in their management in competitions. It is natural for people to experience loss of motivation when they encounter negative emotions. Therefore, although the referees state that they will not be affected, it is possible to have traces of the feelings experienced in the subconscious. Beşler (2016) they were extremely impressed with the personal and social factors of soccer referees in Turkey, the soccer pitch finds that mix the emotions of the tactical management. Çimen (2007) determined that low self-esteem soccer referees could experience intense stress, anxiety, lack of motivation in the competition environment.

One of the second most frequently stated by soccer referees is their negative emotions in their social lives, indicating that they cause stress and concentrate loss in matches. People can spend days where stress and stress increase due to the negative experiences in their social lives, family and work environments. People cannot make the right decisions in extreme stress situations. Therefore, it will not be easy to concentrate on the matches when the soccer referees are stressed. Çakmak (2011) determined that the soccer referees' uneasiness in their social lives was not motivated by the competition and caused a high level of stress.

The second most frequently stated by the soccer referees was the return of the competition with the idea that if negative emotions were experienced in the social life, the right decisions could not be made. Negative emotions can prevent people from making the right decisions in a certain period. It can therefore be said that it would be correct for the referees to return them to the match rather than to manage the matches and to assist the appointment of another referee in the competition. Anshel and Weinberg (1996) found that American and Australian basketball referees thought they were not fair to a stress factor, had negative feelings, and they told that they desired to quit the task.

The least frequently stated by soccer referees is the fact that they can make wrong decisions in competition management as a result of negative emotions in social life. It can be said that negative reactions of soccer referees can affect their ability to make the right decisions. Çimen (2007) found that low self-esteem soccer referees could face intense misdiagnosis. Eygü (2009) found that arbitrators' family problems caused to wrong decisions.

After all, some soccer referees, even if they face negative situations in their social lives, tried to manage fair matches, and they shouldn't reflect these feelings in competitions, no matter what they live in their social lives. Yet, some referees stated that they experienced stress and concentration in competitions when they experienced negative emotions. It should not be forgotten that soccer referees are people and live in a social environment. Therefore, it is considered that it is appropriate to return the matches especially in order to be able to manage competitions during periods of tiredness and stress. It is suggested that the future researches should be done on female referees.

\section{References}

Anshel, M. H., \& Weinberg, R. S. (1996). Coping with acute stress among American and Australian basketball referees. Journal of Sport Behavior, 19(3), 180-203.

Bar-Eli, M., \& Raab, M. (2006). Judgement and decision making in sport and exercise: rediscovery and new visions. Psychology of Sport and Exercise, 7(6), 519-524. https://doi.org/10.1016/j.psychsport.2006.07.003

Baştuğ, G., Duman, S., Akçakoyun, F., \& Karadeniz, F. (2016). Football referees; stress, self-confidence, decision making. Journal of Human Sciences, 13(3), 5399-5406. https://doi.org/10.14687/jhs.v13i3.4213

Beşler, H. K. (2016). The thoughts of football clubs managers coaches and footballers towards football referee's infield management. Master's Thesis, Ankara University Health Sciences Institute, Ankara, Turkey.

Collina, P. (2004). Benim Oyun Kurallarım. (Trans. Gülin Terek Ünal). İstanbul: Altın Kitaplar Publications.

Creswell, J. W. (2007). Qualitative enquiry and research design: Choosing among five approaches. Thousand Oaks, CA: Sage Publishing. 
Çakmak, M. T. (2011). Detection of active football referees stress resource (The case of Ankara Province). Master's Thesis, Ankara University Health Sciences Institute, Ankara, Turkey.

Çimen, S. (2007). To investigation of the personel characteristics the football referees in the area of Ankara. Gazi University Educational Sciences Institute, Ankara, Turkey.

Çoban, D. (2004). Examination of continuous anxiety conditions of classifying referees in charge in professional football leagues of Turkey. Master's Thesis, Selçuk University Health Sciences Institute, Konya, Turkey.

Dohmen, T. J. (2008). The influence of social forces: evidence from the behavior of football referees. Economic Inquiry, 46(3), 411-424. https://doi.org/10.1111/j.1465-7295.2007.00112.x

Eygü, H. (2009). Psychology of sports and research of referee psychology on referees in Turkish football. Master's Thesis, Atatürk University Social Sciences Institute, Erzurum, Turkey.

Grunska, J. (2011). Succesful Sports Officiating. Officiating as a Lifetime Career. $2^{\text {th }}$ Edition, American Sports Education Program. USA.

Guillen, F., \& Feltz, D. L. (2011). A conceptual model of referee efficiacy. Hypothesis and Theory Article, 2(25), 1-5.

Gülle, M., Çetin, M. Ç., Şeker, R., \& Sarı, İ. (2017). Assessment of the correlation between self-esteem in decision-making and decision-making styles of football referees in terms of their refereeing experience and violence perceptions. International Journal of Science Culture and Sport, 5(3), 112-123. https://doi.org/10.14486/IntJSCS657

Gümüş, İ. A. (2009). The study of occupational exhausting degree of the referees working in the third region. Master's Thesis, Dumlupınar University Social Sciences Institute, Kütahya, Turkey.

Katırc1, H. (2009). Corporate communication management in Turkish football. Gazi Physical Education and Sports Sciences Journal, XIV (4), 65-75.

Marcora, S. M., Staiano, W., \& Manning, V. (2009). Fatigue impairs physical performance in humans. Journal of Applied Physiology, 106 (3), 857-864. https://doi.org/10.1152/japplphysiol.91324.2008

Mckeon, D. (2003). The football referee. The Referees' Association, England.

Nevill, A. M., Balmer, N. J., \& Williams, A. M. (2002). The influence of crowd noise and experience upon refereeing decisions in football. Psychology of Sport and Exercise Elsevier Science, 3(4), 261-272. https://doi.org/10.1016/S1469-0292(01)00033-4

Patton, M. Q. (2014). Nitel araştırma ve değerlendirme yöntemleri. (M. Bütün ve S. B. Demir Ed.). Ankara: Pegem Publisher.

Punch, K. F. (2005). Sosyal araştırmalara giriş (Trans. D. Bayrak, H. B. Arslan, Z. Akyüz). Ankara: Siyasal Publications.

Rue, L. W., \& Byars, L. L. (2003). Decision making skills. Management Skills and Application, $10^{\text {th }}$ Edition, Mc-Graw Hill, New York.

Rushall, B. S., \& Lippman, L. G. (1997). The role of refereees in physical performance. International Journal of Sport Psychology, 29 (1), 57-72.

Scoppa, V. (2008). Are subjective evaluations biased by social factors or connections? An econometric analysis of soccer referee decisions. Munich Personal RePEc Archive (MPRA), 1-20. https://doi.org/10.1007/s00181-007-0146-1

Tavşancıl, E., \& Aslan, E. (2001). İ̧̧erik analizi ve uygulama örnekleri. İstanbul: Epsilon Publications.

Tekin, A. H., Savucu, Y., \& Ramazan, F. (2005). Social Status and Problems of Classifying and Region Referees, Firat University Journal of Social Science, 15(2), 209-217.

Yıldırım, A., \& Şimşek, H. (2006). Sosyal bilimlerde nitel araştırma yöntemleri. Ankara: Seçkin Publications.

\section{Copyrights}

Copyright for this article is retained by the author(s), with first publication rights granted to the journal.

This is an open-access article distributed under the terms and conditions of the Creative Commons Attribution license which permits unrestricted use, distribution, and reproduction in any medium, provided the original work is properly cited. 